\title{
Chemically Enhanced Biodegradation of High Organic Matter in Wastewater - Confectionary Plant Effluents
}

\author{
Işık Kabdaşıı 1,*(i), Olcay Tünay ${ }^{2}$ (i) , Derin Orhon ${ }^{3(\mathbb{D})}$ \\ 1 Environmental Engineering Department, Civil Engineering Faculty, Istanbul Technical University, Ayazağa Campus, \\ 34469, Sarıyer, Istanbul, Turkey; kabdasli@itu.edu.tr (I.K.); \\ 2 Environmental Engineering Department, Civil Engineering Faculty, Istanbul Technical University, Ayazağa Campus, \\ 34469, Sariyer, Istanbul, Turkey; tunayol@itu.edu.tr; (O.T.); \\ 3 The Science Academy, 34349, Istanbul, Turkey; orhon@itu.edu.tr; (D.O.); \\ * Correspondence: kabdasli@itu.edu.tr;
}

Scopus Author ID 6701585725

Received: 30.05.2021; Revised: 25.09.2021; Accepted: 28.09.2021; Published: 19.11.2021

\begin{abstract}
The study explored the merit of chemically enhanced biodegradation of high organic matter as a sustainable treatment scheme for industrial wastewaters. For this purpose, an integrated, chemically enhanced activated sludge configuration was tested for confectionary effluents with a COD level of around $10.000 \mathrm{mg} \mathrm{L}^{-1}$. In this configuration, chemical settling acted as a polishing step, which removed $50 \%$ of the total COD load, including $10 \%$ of colloidal COD in the soluble COD range. The sequential batch reactor, selected as the final biological treatment step, was able to remove the remaining biodegradable COD completely. The study primarily demonstrated the merit of in-plant pollution footprint assessment and wastewater characterization with significant COD fractions as necessary prerequisites for the management and final biodegradation of industrial wastewaters with high organic matter content.
\end{abstract}

Keywords: biodegradation; chemical settling; COD fractionation; confectionery industry; pollution footprint; sequencing batch reactor; strong wastewater.

(C) 2021 by the authors. This article is an open-access article distributed under the terms and conditions of the Creative Commons Attribution (CC BY) license (https://creativecommons.org/licenses/by/4.0/).

\section{Introduction}

The activated sludge process was discovered and implemented for sewage, wastewater with moderate organic matter content in the range of 400 to $600 \mathrm{mg} \mathrm{COD} \mathrm{L}^{-1}$ [1]. The satisfactory performance of treatment plants severely deteriorated in the face of industrial effluents with much higher organic loads and micro-chemicals; observed problems triggered efforts to develop process modifications restoring the stability of the microbial culture that ensured good performance [2,3]. Nevertheless, accumulated information and experience on the nature of substrate and biomass indicated that complete biodegradation of high COD levels could not be achieved in single-stage biological processes [4,5]: anaerobic treatment is inherently incapable to reduce the effluent down to meet effluent limitations and requires the following polishing stage of aerobic treatment [6-9]. Activated sludge configurations alone would also confront a number of severe problems such as oxygen shortage; excessive generation of residual metabolic products; sludge bulking and foaming, which would impede biodegradation and process efficiency; depending on the nature of the wastewater to be treated, they need the support of either an anaerobic step or a wide array of chemical processes as pretreatment $[10,11]$ Strong industrial effluents with excessive COD loads are well explored in 
studies, which generally confirmed the need of two-stage treatment [12-17]. The majority of experimental assessments implemented and successfully tested chemical settling, as a simple and reliable pre-treatment before the final activated sludge step [18-24].

This study selected confectionary plant effluents for a sustainable treatment strategy. The confectionery industry is an important branch of the food industry with a high potential for organic pollution. The industry produces various products such as candies, bars, etc., and it generates an effluent with a COD level of around $10.000 \mathrm{mg} \mathrm{L}^{-1}$. Although the organic matter is mainly readily biodegradable [25-27], this COD level is too high to meet the discharge standards into the receiving media. Therefore, studies suggested two-stage biological systems, generally a sequence of anaerobic/aerobic processes, as the appropriate treatment scheme. Berardino et al. [28] investigated anaerobic digestion of confectionery industry wastewater with COD of $0.53-2.62 \mathrm{~g} \mathrm{~L}^{-1}$ and obtained COD removals higher than $80 \%$. Methane content of the biogas produced varied between 84.3 - 89.9\% conducted on a waste survey for a confectionery plant and operated an anaerobic expanded granular sludge bed (EGSB) reactor as a pretreatment before conventional aerobic treatment. The average COD removal and biogas production for the EGSB reactor were reported as $88 \%$ and1730 $\mathrm{Nm}^{3}$ day $^{-1}$, respectively. Balcığlu et al. [29] operated an anaerobic membrane bioreactor (AnMBR) system to treat wastewater originating from a confectionery plant. 99\% COD removals were obtained, and methane yield was $0.31 \mathrm{~L} \mathrm{CH}_{4}(\mathrm{~g} \mathrm{COD})^{-1}$ removed at organic loading of $4.4 \mathrm{~kg} \mathrm{COD}\left(\mathrm{m}^{3} . \mathrm{d}\right)^{-1}$. A relatively early study tested a two-stage anaerobic treatment approach [30], where the COD removal from the confectionery wastewater was investigated by means of a bench-scale sequential anaerobic treatment system; in this study, an up-flow anaerobic sludge blanket reactor (UASB;) followed by a down-flow anaerobic filter (DFAF) was operated at $35^{\circ} \mathrm{C}$ and $25{ }^{\circ} \mathrm{C}$, respectively. COD concentration was reduced from 30 to $0.3 \mathrm{~g} \mathrm{~L}^{-1}$ at a total organic loading of $5 \mathrm{~kg} / \mathrm{m}^{3} / \mathrm{d}$ and a total hydraulic retention time of $2.4 \mathrm{~d}$. Review of the available information in the literature indicated no study testing the merit of chemical settling as a pretreatment step for this wastewater.

In this context, the study's objective was to explore the merit of an integrated, chemically enhanced activated sludge configuration as a sustainable treatment scheme for confectionary effluents. In this configuration, chemical settling acted as a polishing step for the sequencing batch reactor (SBR), adopted as the second stage of activated sludge modification for biological treatment.

\section{Materials and Methods}

\subsection{Production scheme.}

The confectionary plant selected for the study produces a wide spectrum of products. It is kept in operation on three shifts a day and six days a week basis. The number of total personnel varies between 150-300 depending on production requirements. Production processes in the plant can be classified into three groups. The first group covers the production of the main materials used to prepare all products. These main products are chocolate, creme, and chocolate creme. The preparation of these materials involves similar procedures of mixing and grinding raw materials such as sugar, milk powder, cocoa, emulsifier, vegetable oil, and natural flavor. Process materials are conveyed into storage tanks, from which they are fed to different production schemes. The second group of production involves the manufacturing of semi-products such as fondants and marshmallows. These production groups are carried out in 
reactors that may be heated with non-contact steam and mixing, followed by beating and cooling operations. Manufacture of the final products such as chocolate-coated bars, candies, chocolate-coated wafers, etc., constitutes the third group. In this group, the main operations are mixing, shaping, cooling, cutting, and packaging. A representative example of the footprint of chocolate-coated wafer production is schematically shown in Figure 1.

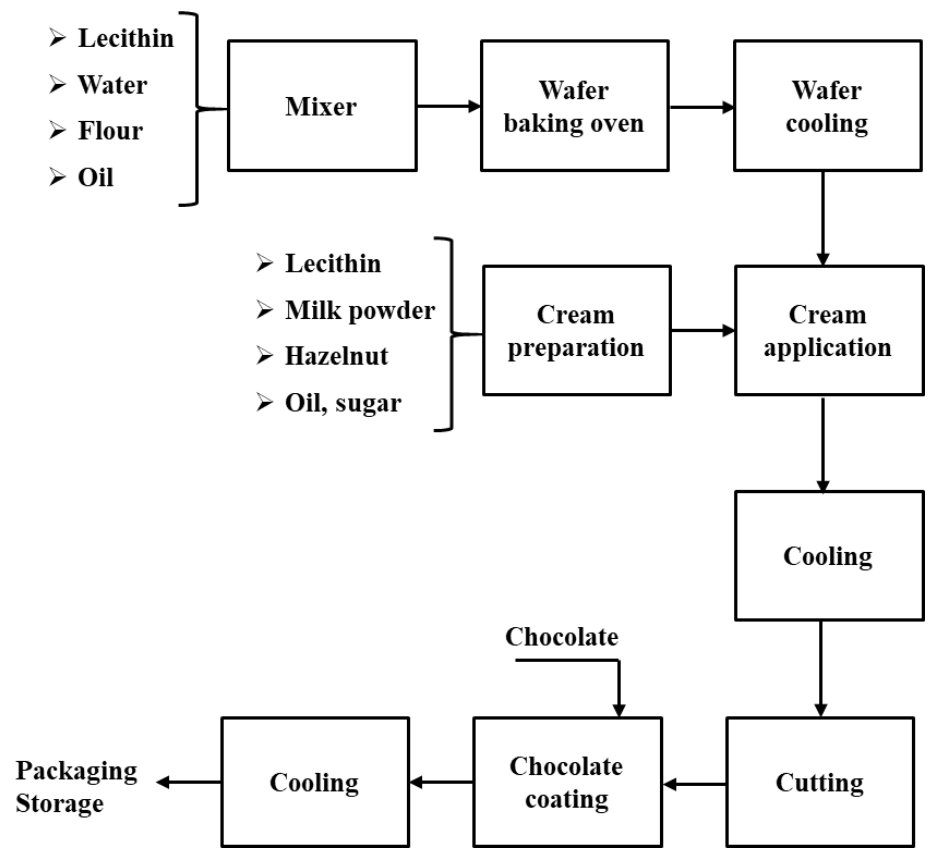

Figure 1. Process footprint of the chocolate-coated wafer (Product II).

The total production capacity of the plant is given in Table 1 . The capacity of the plant in terms of final products is given in Table 1, in terms of five major products, namely is a marshmallow sandwiched between two biscuits and coated with chocolate (Product I); chocolate creme covered bars of caramel (Product II); chocolate-coated wafer (Product III); chocolate-coated bars of fruit paste (Product IV) and crème of chocolate (Product V).

Table 1. The production capacity of the selected confectionary.

\begin{tabular}{l|c|c} 
& Total production (ton year ${ }^{-1}$ ) & Production time (hour year ${ }^{-\mathbf{1}}$ ) \\
\hline Marshmallow sandwiched biscuits & 3800 & 11120 \\
\hline Caramel bar & 300 & 800 \\
\hline Chocolate-coated wafer & 980 & 5300 \\
\hline Chocolate-coated bars of fruit paste & 235 & 900 \\
\hline Crème of chocolate & 750 & 5500
\end{tabular}

\subsection{Wastewater footprint.}

The traditional end-of-pipe inspection of wastewater is perhaps the worst applicable approach for industrial effluents, which generally exhibit significant flow and pollutant loads variations depending on the production scheme of confectionery plants. Instead, a footprint analysis based on a detailed in-plant survey emerged as an effective way to assess the relationships between production steps and pollutant generation and to derive essential data for wastewater management. A typical example of the footprint approach was reported for a textile dye house processing different fabrics [31]. A similar method was used to evaluate energy recovery based on sludge footprints in municipal treatment plants [32]. The same methodology was adopted in this study, which indicated that the wastewater sources could be classified into 
three different groups: The first group involved equipment washing and cleaning. The second group was washing the machine parts and/or the rejected products in the dishwashing center. The third group was floor washing and cleaning. Washing of equipment and some material tanks was performed on an intermittent basis. Wastewater sources and volumes determined on the basis of the in-plant survey are tabulated in Table 2. It should be noted that some of the equipment such as silos, storage tanks are cleaned using oil being partly recovered or disposed of as hazardous waste.

Table 2. Wastewater sources and volumes derived from footprint analysis.

\begin{tabular}{l|l|l|l|l} 
& \multicolumn{2}{|c|}{ Equipment Washing } & Dish-Washing & \\
\hline & Frequent & Infrequent & Center & Floor washing \\
\hline Chocolate creme & - & $17 \mathrm{~m}^{3}(2 \mathrm{y})^{-1}$ & - & - \\
\hline Chocolate & - & $6 \mathrm{~m}^{3} \mathrm{y}^{-1}$ & - & - \\
\hline Creme & - & $16 \mathrm{~m}^{3}(2 \mathrm{y})^{-1}$ & - & - \\
\hline Marshmallow & $0.80 \mathrm{~m}^{3} \mathrm{w}^{-1}$ & - & - & - \\
\hline Fondant & $0.15 \mathrm{~m}^{3} \mathrm{~d}^{-1}$ & - & - & $0.5 \mathrm{~m}^{3} \mathrm{~d}^{-1}$ \\
\hline Product I & - & - & - & $0.5 \mathrm{~m}^{3} \mathrm{~d}^{-1}$ \\
\hline Product II & - & $0.20 \mathrm{~m}^{3} \mathrm{~d}^{-1}$ & - & - \\
\hline Product III & $0.25 \mathrm{~m}^{3} \mathrm{~d}^{-1}+0.20 \mathrm{~m}^{3} \mathrm{w}^{-1}$ & - & $0.30 \mathrm{~m}^{3} \mathrm{~d}^{-1}$ & $0.06 \mathrm{~m}^{3} \mathrm{~d}^{-1}$ \\
\hline Product IV & $0.20 \mathrm{~m}^{3} \mathrm{~d}^{-1}$ & - & - & $1.5 \mathrm{~m}^{3} \mathrm{~d}^{-1}$ \\
\hline Product V & & $0.20 \mathrm{~m}^{3} \mathrm{~d}^{-1}$ & $3.0 \mathrm{~m}^{3} \mathrm{~d}^{-1}$ & - \\
\hline Total & & & $3.85 \mathrm{~m}^{3} \mathrm{~d}^{-1}$ & $2.56 \mathrm{~m}^{3} \mathrm{~d}^{-1}$
\end{tabular}

Table 2 shows wastewater sources and wastewater amounts generated from the investigated plant. Although all productions are fed through central raw material production, the equipment washing effluents are rather infrequent and have a limited contribution to the total wastewater volume. Since the dishwashing center wastewaters are the most important sources in terms of both quality and quantity, while products IV and V play a key role in wastewater generation, the continuous effluent from product $\mathrm{V}$ can be considered as the decisive step in affluent generation in terms of the overall wastewater quality and quantity. In general, the central dishwashing and those products necessitating the use of this center are important in evaluating the pollution characteristics in confectionery industries.

\subsection{Wastewater characterization.}

As mentioned above, the major process wastewater source was the dishwashing center; two types of samples were collected from this center as displayed in Table 3: Concentrated samples represented the pre-wash containing a heavy load of contaminants. Grab samples were collected since the flow of pre-wash takes a very short time. The second type sample taken from the dishwashing center was a composite sample of final washing and rinse, which flows for several hours. The volume of the concentrated wastewater was approximately $20 \%$ of the total effluent flow.

Table 3. Dishwashing center and cafeteria wastewater characterization.

\begin{tabular}{l|l|l|l|l} 
& $\begin{array}{l}\text { COD } \\
(\mathbf{m g ~ L}\end{array}$ & $\begin{array}{l}\text { BOD } \\
\left(\mathbf{m g ~ L}^{-1}\right)\end{array}$ & $\begin{array}{l}\text { Oil\&Grease } \\
\left(\mathbf{m g ~ L}^{-1}\right)\end{array}$ & $\mathbf{p H}$ \\
\hline Concentrated I & 59500 & 39000 & 1420 & 6.0 \\
\hline Concentrated II & 22550 & - & 320 & 7.4 \\
\hline Composite I & 10250 & 15750 & - & 5.8 \\
\hline Composite II & 19220 & - & 532 & 4.6 \\
\hline Composite III & 14400 & - & - & 6.5
\end{tabular}




\subsection{Experimental set-up.}

Bench-scale experiments were conducted using an effluent sample of the plant prepared by mixing the overall composite samples VI and $\mathrm{V}$ at an equal 1:1 ratio on a volume basis and passing the mixture through a $3 \mathrm{~mm}$-opening screen.

Chemical treatment experiments were run using a $1000 \mathrm{~mL}$-capacity Jar-Test apparatus. 5 minutes flash-mixing at $100 \mathrm{rpm}, 15$ minutes flocculation at $30 \mathrm{rpm}$, and 2 hours settling sequence were followed. $\mathrm{FeCl}_{3} \cdot 6 \mathrm{H}_{2} \mathrm{O}, \mathrm{FeSO}_{4} \cdot 7 \mathrm{H}_{2} \mathrm{O}$, and $\mathrm{Al}_{2}\left(\mathrm{SO}_{4}\right)_{3} \cdot 18 \mathrm{H}_{2} \mathrm{O}$, were used as coagulants. $\mathrm{pH}$ adjustment was made with lime. Analyses were carried out on the supernatant of the chemically treated samples.

Biological treatment experiments were performed using a 2-L batch reactor equipped with porous stone diffusers to supply air. Activated sludge seed provided from a domestic wastewater treatment plant was acclimated for a month at an organic loading of $1 \mathrm{~g}$ COD ( $\mathrm{g}$ MLVSS.day) ${ }^{-1}$. A mixture of urea, $\mathrm{KH}_{2} \mathrm{PO}_{4}$, and $\mathrm{K}_{2} \mathrm{HPO}_{4}$ was added to supply the nutrients and buffer $\mathrm{pH}$. The soluble COD measurements monitored activated sludge process performance. Filtration was made using Millipore $0.45 \mu \mathrm{m}$ membrane filters.

All chemicals used were of analytical grade. All analyses were made in accordance with Standard Methods [33].

\section{Results and Discussion}

In the plant, process wastewaters cannot be separately collected from domestic wastewaters. The main sewer of the plant carried all process effluents as well as domestic wastewaters. Two daily composite samples, which covered all production activities in the plant, were prepared from this sewer. Table 4 shows the analytical results of these daily composite samples, which accurately reflect the characteristics of the overall plant effluent.

Table 4. Overall characteristics of the plant effluent based on daily composite samples.

\begin{tabular}{l|l|l|l} 
Parameter & Unit & Composite IV & Composite V \\
\hline Total COD & $\mathrm{mg} \mathrm{L}^{-1}$ & 9950 & 9170 \\
\hline Settled COD & $\mathrm{mg} \mathrm{L}^{-1}$ & 6470 & 6925 \\
\hline Filtered COD & $\mathrm{mg} \mathrm{L}^{-1}$ & 3520 & 6650 \\
\hline Total BOD & $\mathrm{mg} \mathrm{L}_{5}$ & 2970 & 6640 \\
\hline Settled BOD 5 & $\mathrm{mg} \mathrm{L}^{-1}$ & 2660 & 6100 \\
\hline Filtered BOD 5 & $\mathrm{mg} \mathrm{L}^{-1}$ & 2360 & 5500 \\
\hline Oil and grease & $\mathrm{mg} \mathrm{L}^{-1}$ & 320 & 570 \\
\hline TKN & $\mathrm{mg} \mathrm{L}^{-1}$ & 56 & 73 \\
\hline TP & $\mathrm{mg} \mathrm{P} \mathrm{L}^{-1}$ & 2.3 & 3.1 \\
\hline pH & - & 6.0 & 5.9
\end{tabular}

The total COD values in Table 4 also include the input of coarse particles, which were broken down by blending before analysis. These coarse particles can be screened before treatment, as mentioned in the following section. Characterization of composite wastewater samples also included a preliminary fractionation of COD in terms of total COD, supernatant of plain settling (settled COD), and filtrate through $450 \mathrm{~nm}$ filters (soluble COD) components; the same characterization was also carried out for $\mathrm{BOD}_{5}$, which seems to be correlated with the soluble COD fraction. Currently, this type of preliminary COD fractionation has been improved into an elaborate particle size distribution (PSD) analysis in a much larger size spectrum down to $2.0 \mathrm{~nm}$, and it is widely applied to both sewage and industrial wastewaters $[34,35]$. It is interesting to note the oil-grease as high as $570 \mathrm{mg} \mathrm{L}^{-1}$, which qualifies to be a hard-to-treat parameter for anaerobic processes. 


\subsection{Treatment rationale.}

Inspection of the wastewater characteristics reveals two significant clues: (i) an influent COD level of around $9500 \mathrm{mg} \mathrm{L}^{-1}$ is too high to comply with the effluent treatment by means of a single-stage treatment, whether it be an anaerobic or an aerobic process. (ii) it is particularly suitable for the envisaged chemically enhanced activated sludge process.

In fact, the analyses indicated a COD removal potential of around 30\%, even with plain settling. Thus, a chemically induced settling would be expected to remove all particulate organic matter as well as a portion of what was assessed as soluble COD. This way, it would also homogenize the wastewater character before being fed into the aerobic treatment stage. A sequencing batch reactor (SBR) was selected as an activated sludge configuration for the aerobic biological treatment stage, mainly because of the well-tested operation flexibility of the SBR process for variations of wastewater volume and strength as well as for settling character.

\subsection{Chemical settling.}

The results of chemical settling experiments through coagulation-flocculation experiments conducted using three different coagulants, alum, $\mathrm{FeSO}_{4}$, and $\mathrm{FeCl}_{3}$, at dosages varying between 250 and $750 \mathrm{mg} \mathrm{L}^{-1}$, are given in Table 4 . The data provided a clear indication that all coagulants, when applied at dosages of 250-300 $\mathrm{mg} \mathrm{L}^{-1}$, yielded a COD removal that varied in the narrow range of $51-55 \%$, including the preliminary screening. Increasing the $\mathrm{FeSO}_{4}$ dosage to $750 \mathrm{mg} \mathrm{L}^{-1}$ did not prove feasible as it resulted in a slight increase in the COD removal to $58 \%$. Interestingly, all effluent COD concentrations obtained after chemical settling averaged $4500 \mathrm{mg} \mathrm{L}^{-1}$, appreciably lower than the soluble level of $5000 \mathrm{mg} \mathrm{L}^{-1}$ in the tested mixture. This observation showed that chemical settling provided full removal of particulate COD and $10 \%$ of the colloidal COD below the size threshold of $450 \mathrm{~nm}$. This treatment step also secured the complete removal of suspended solids as well as oil and grease.

Table 5. Results of Chemical Treatment.

\begin{tabular}{l|l|l|l|l} 
Coagulant & $\begin{array}{l}\text { Dosage } \\
\left(\mathbf{m g ~ L} \mathbf{~ L}^{-1}\right)\end{array}$ & $\mathbf{p H}$ & $\begin{array}{l}\text { Effluent COD } \\
\left(\mathbf{m g ~ L} \mathbf{~ L}^{-1}\right.\end{array}$ & $\begin{array}{l}\text { COD Removal } \\
(\mathbf{\%})\end{array}$ \\
\hline $\mathrm{Al}_{2}\left(\mathrm{SO}_{4}\right)_{3}$ & 250 & 6.7 & 4685 & 30 \\
\hline $\mathrm{Al}_{2}\left(\mathrm{SO}_{4}\right)_{3}$ & 300 & 6.7 & 4660 & 30 \\
\hline $\mathrm{FeCl}_{3}$ & 250 & 8.0 & 4530 & 32 \\
\hline $\mathrm{FeCl}_{3}$ & 250 & 9.0 & 4320 & 36 \\
\hline $\mathrm{FeSO}_{4}$ & 250 & 8.3 & 4440 & 34 \\
\hline $\mathrm{FeSO}_{4}$ & 750 & 8.5 & 4030 & 40
\end{tabular}

\subsection{Biological treatment.}

The successful application of SBR, mainly due to its flexibility of operation for different types of wastewaters, is widely reported in the literature [36-40]. In this study, the operation of the lab-scale SBR unit was adjusted to a cycle time of 1.0 days, with a processing time, $\mathrm{T}_{\mathrm{P}}$ of $22 \mathrm{~h}$, and an additional $2.0 \mathrm{~h}$ for settle; decant; idle period. The feeding time, $\mathrm{T}_{\mathrm{F}}$, covered the first $5.0 \mathrm{~h}$ of the cycle, as in fill and draw-type of an operation. The effluent of chemical treatment $\left(\mathrm{FeSO}_{4}\right.$ experiment at $\left.250 \mathrm{mg} \mathrm{L}^{-1}\right)$ was selected as the wastewater feed, which sustained a biomass concentration of $4000-4500 \mathrm{mg} \mathrm{MLSS} \mathrm{L}^{-1}$ at a steady state. The performance of the SBR system under different organic loadings is outlined in Table 6. 


\begin{tabular}{l|l|l}
$\begin{array}{l}\text { Organic load } \\
\left(\mathrm{gCOD}(\mathrm{g} \mathrm{MLVSS} . \mathrm{d})^{-1}\right)\end{array}$ & $\begin{array}{l}\text { Effluent COD } \\
\left(\mathrm{mg} \mathrm{L}^{-1}\right)\end{array}$ & $\begin{array}{l}\text { Removal } \\
\%\end{array}$ \\
\hline 1.69 & 115 & 97 \\
\hline 1.51 & 110 & 97 \\
\hline 1.13 & 100 & 98 \\
\hline 0.93 & 90 & 98 \\
\hline 0.76 & 90 & 98
\end{tabular}

As seen from Table 5, the SBR system yielded very high COD removals even for the highest organic loadings. Decreasing the organic loading did not further increase the COD removal efficiency. Lower organic loadings resulted in the same efficiencies indicating that all biodegradable COD was fully utilized at almost all organic loadings rates, and the effluent COD corresponded to the soluble residual metabolic products generated in the course of biological reactions in the reactor, as confirmed by the glucose test performed in accordance with the methodology recommended by Germirli et al. [41]. Flocculent settling of the biomass was quite good with an average SVI value of $75 \mathrm{~mL} \mathrm{~g}^{-1}$, and the effluent suspended solid concentration always remained lower than $40 \mathrm{mg} \mathrm{L}^{-1}$.

\subsection{Recommended treatment scheme.}

The pollutant footprint analyses and differentiation of organic matter in terms of settled and filtered COD fractions provided significant clues for a sustainable treatment scheme: (i) substantial load and flow variations in different effluent streams; (ii) the low magnitude of total daily effluent flow; (iii) a total COD level of approximately $10.000 \mathrm{mg} \mathrm{L}^{-1}$, which necessitates a two-stage treatment. Based on these indications, treatability studies justified the application of a sequence of chemical settling and SBR that would be operated batch-wise, involving the following configuration: a separate collection and pre-treatment of individual waste streams; an aerated equalization tank with sufficient volume to allow batch feeding of the main treatment sequence; a chemical treatment tank that can function both as a reactor and a settler and an SBR unit. A schematic display of the proposed treatment scheme is displayed in Figure 2.

\section{Conclusions}

The study primarily demonstrated the merit of in-plant pollution footprint assessment and COD characterization with differentiation of particulate, settled and soluble fractions in the effluent as necessary prerequisites for the management and final biodegradation of industrial wastewaters with high organic matter content. It also underlined the need for particle size distribution analysis as a useful complement of biodegradation experiments. This approach constituted the basis for assessing the treatability of the confectionary effluents, which identified a two-step chemically enhanced SBR system as the sustainable treatment scheme; wastewater characteristics were particularly suitable for chemical settling, which provided 50\% removal of the total COD load, including $10 \%$ of colloidal COD in the soluble COD range. The sequential batch reactor, selected as one of the most convenient types of biological treatment for batch operation, achieved full removal of biodegradable COD, leaving only soluble residual metabolic products of around $100 \mathrm{mg} \mathrm{COD} \mathrm{L}^{-1}$ in the effluent. 


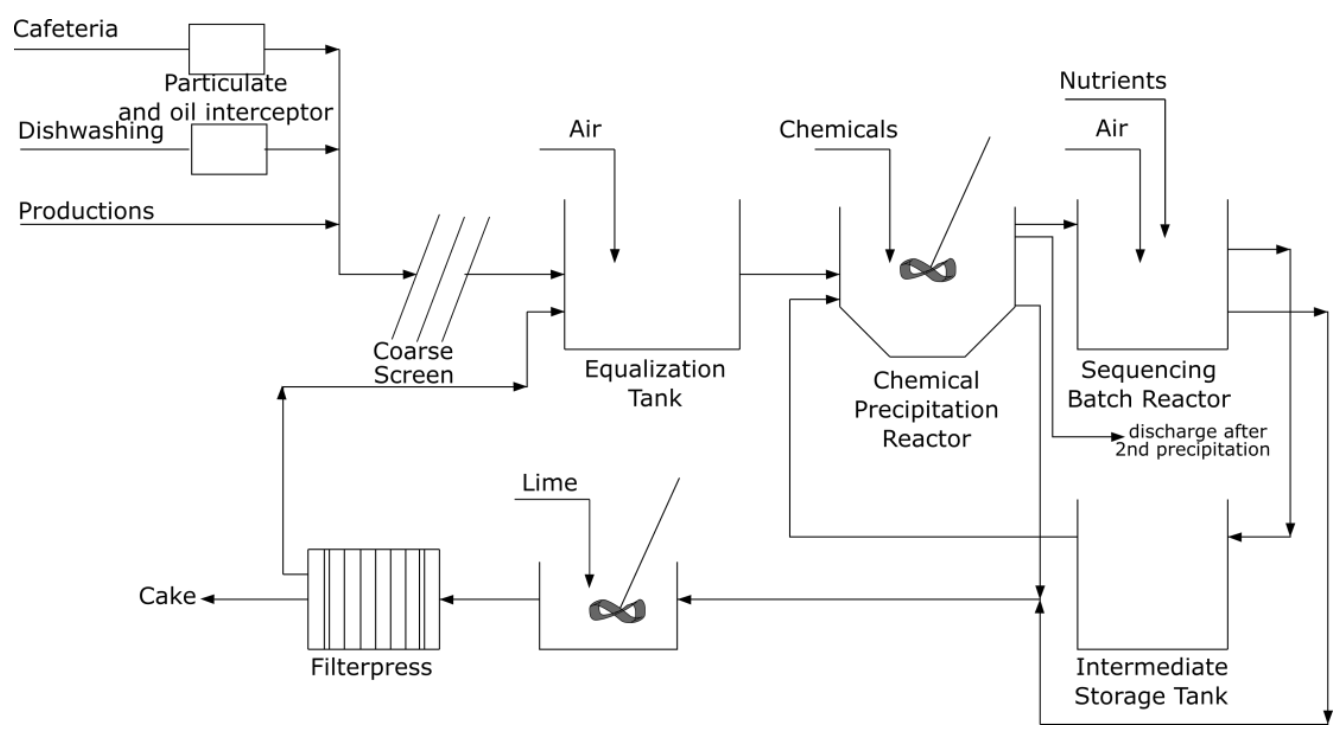

Figure 2. Recommended chemically enhanced SBR treatment.

\section{References}

1. Tas, D.O.; Karahan, O.; Insel, G.; Ovez, S.; Orhon, D.; Spanjers, H. Biodegradability and Denitrification Potential of Settleable Chemical Oxygen Demand in Domestic Wastewater. Water Environment Research 2009, 81, 715-727, https://doi.org/10.2175/106143009x425942.

2. Orhon, D. Evolution of the activated sludge process: the first 50 years. Journal of Chemical Technology and Biotechnology 2015, 90, 608-640, https://doi.org/10.1002/jctb.4565.

3. Orhon, D.; Sozen, S. Reshaping the activated sludge process: has the time come or passed? Journal of Chemical Technology and Biotechnology 2020, 95, 1632-1639, https://doi.org/10.1002/jctb.6290.

4. Abidi, M.A.; Hairom, N.H.H.; Madon, R.H.; Kassim, A.S.M.; Sidik, D.A.; Al-Gheethi, A.A.S. Optimization Of Microbial Consortium (AB-101) Performance In Palm Oil Mill Effluent (POME) Treatment Via Response Surface Methodology (RSM). Biointerface Research in Applied Chemistry 2021, 11, 9242-9252, https://doi.org/10.33263/briac112.92429252.

5. Insel, G.; Kendir, E.; Ayol, A.; Erdincler, A.; Arikan, O.; Imamoglu, I.; Alagoz, B.A.; Gencsoy, E.B.; Sanin, F.D.; Buyukkamaci, N.; Karatas, O.; Saygili, G.; Sener, G.; Ubay Cokgor, E.; Filibeli, A. Current Situation and Future Perspectives in Municipal Wastewater Treatment and Sludge Management in Turkey. Journal of Residuals Science \& Technology 2013, 10, 133-138.

6. Ozgun, H.; Karagul, N.; Dereli, R.K.; Ersahin, M.E.; Coskuner, T.; Ciftci, D.I.; Ozturk, I.; Altinbas, M. Confectionery industry: a case study on treatability-based effluent characterization and treatment system performance. Water Science and Technology 2012, 66, 15-20, https://doi.org/10.2166/wst.2012.094.

7. Germirli, F.; Orhon, D.; Artan, N.; Ubay, E.; Gorgun, E. Effect of two-stage treatment on the biological treatability of strong industrial-wastes. Water Science and Technology 1993, 28, 145-154.

8. Tociu, C.; Maria, C.; Marcu, E.; Ionescu, P.; Radu, M.V. The effect of wastewater from paper mills on the operation of primary stages in the municipal wastewater treatment plant. Biointerface Research in Applied Chemistry 2017, 7, 2063-2066.

9. Decio, A.A.; Oro, C.E.D.; dos Santos, M.S.N.; Dallago, R.M.; Tres, M.V. Integration of Improved Methods for the Treatment of Wastewater from a Soft Drink Industry. Biointerface Research in Applied Chemistry 2021, 11, 12946-12957, https://doi.org/10.33263/briac115.1294612957.

10. Fagier, M.A.; Salaheldeen, M.; Abdalrhman, M.O. Combination of Persulfate /Peroxymonosulfate Activated By Ion (II) with Hydrogen Peroxide for Mineralization and Valorization of Vinasse. Biointerface Research in Applied Chemistry 2021, 11, 7519-7527, https://doi.org/10.33263/briac111.75197527.

11. Ciggin, A.S.; Ozcan, O.O.; Gokcekus, H.; Orhon, D. Effect of Fenton oxidation on the toxicity of carpet manufacturing effluents. Desalination and Water Treatment 2021, 215, 268-278, https://doi.org/10.5004/dwt.2021.26394.

12. Lofrano, G.; Meric, S.; Zengin, G.E.; Orhon, D. Chemical and biological treatment technologies for leather tannery chemicals and wastewaters: A review. Science of the Total Environment 2013, 461, 265-281, https://doi.org/10.1016/j.scitotenv.2013.05.004.

13. Kabdaşl1, I.; Gürel, M.; Tünay, O. Characterization and treatment of textile printing wastewaters. Environmental Technology 2000, 21, 1147-1155, https://doi.org/10.1080/09593330.2000.9619001.

14. Tünay, O.; Samuk, B.; Olmez, T.; Kabdaşl1, I. Application of advanced oxidation to enhance biodegradability of pharmaceutical industry wastewaters. Fresenius Environmental Bulletin 2004, 13, 965-968. 
15. Kabdaşlı, I.; Gürel, M.; Tünay, O. Pollution prevention and waste treatment in chemical synthesis processes for pharmaceutical industry. Water Science and Technology 1999, 39, 265-271, https://doi.org/10.1016/s0273-1223(99)00287-5.

16. Kabdaşl1, I.; Tünay, O.; Ozcan, P. Application of struvite precipitation coupled with biological treatment to slaughterhouse wastewaters. Environmental Technology 2009, 30, 1095-1101, https://doi.org/10.1080/09593330903136856.

17. Kabdaşl1, I.; Şafak, A.; Tünay, O. Bench-scale evaluation of treatment schemes incorporating struvite precipitation for young landfill leachate. Waste Management 2008, 28, 2386-2392, https://doi.org/10.1016/j.wasman.2007.10.020.

18. Kastali, M.; Mouhir, L.; Chatoui, M.; Souabi, S.; Anouzla, A. Removal of Turbidity and Sludge Production from Industrial Process Wastewater Treatment by a Rejection of Steel Rich in FeCl3 (SIWW). Biointerface Research in Applied Chemistry 2021, 11, 13359-13376, https://doi.org/10.33263/briac115.1335913376.

19. Halip, J.A.; Lee, S.H.; Tahir, P.M.; Chuan, L.T.; Selimin, M.A.; Saffian, H.A. A Review: Chemical Treatments of Rice Husk for Polymer Composites. Biointerface Research in Applied Chemistry 2021, 11, 12425-12433, https://doi.org/10.33263/briac114.1242512433.

20. Kabdaşl1, I.; Tünay, O.; Çetin, M.S.; Olmez, T. Assessment of magnesium ammonium phosphate precipitation for the treatment of leather tanning industry wastewaters. Water Science and Technology 2002, 46, 231-239.

21. Meriç, S.; Kabdaşl1, I.; Tünay, O.; Orhon, D. Treatability of strong wastewaters from polyester manufacturing industry. Water Science and Technology 1999, 39, 1-7, https://doi.org/10.1016/s0273-1223(99)00247-4.

22. Tünay, O.; Yelmez, Z.B.; Olmez, T.; Kabdaşl1, I. Residual COD reduction in biologically treated leather tanning effluents by advanced treatment processes. Journal of the American Leather Chemists Association 2006, 101, 123-131.

23. Tünay, O.; Orhon, D.; Kabdaşl1, I. Pretreatment requirements for leather tanning industry wastewaters. Water Science and Technology 1994, 29, 121-128.

24. Dogruel, S.; Germirli-Babuna, F.; Kabdasli, I.; Insel, G.; Orhon, D. Effect of stream segregation on ozonation for the removal of significant COD fractions from textile wastewater. Journal of Chemical Technology and Biotechnology 2003, 78, 6-14, https://doi.org/10.1002/jctb.713.

25. Orhon, D.; Sozen, S.; Artan, N. The effect of heterotrophic yield on the assessment of the correction factor for anoxic growth. Water Science and Technology 1996, 34, 67-74, https://doi.org/10.1016/02731223(96)00630-0.

26. Orhon, D.; Yildiz, G.; Cokgor, E.U.; Sozen, S. Respirometric evaluation of the biodegradability of confectionary wastewaters. Water Science and Technology 1995, 32, 11-19, https://doi.org/10.1016/02731223(96)00133-3.

27. Zajda, M.; Aleksander-Kwaterczak, U. Wastewater Treatment Methods for Effluents from the Confectionery Industry - an Overview. Journal of Ecological Engineering 2019, 20, 293-304, https://doi.org/10.12911/22998993/112557.

28. Di Berardino, S.; Costa, S.; Converti, A. Semi-continuous anaerobic digestion of a food industry wastewater in an anaerobic filter. Bioresource Technology 2000, 71, 261-266, https://doi.org/10.1016/s09608524(99)00080-2.

29. Balcioglu, G.; Yilmaz, G.; Gonder, Z.B. Evaluation of anaerobic membrane bioreactor (AnMBR) treating confectionery wastewater at long-term operation under different organic loading rates: Performance and membrane fouling. Chemical Engineering Journal 2021, 404, https://doi.org/10.1016/j.cej.2020.126261.

30. Beal, L.J.; Raman, D.R. Sequential two-stage anaerobic treatment of confectionery wastewater. Journal of Agricultural Engineering Research 2000, 76, 211-217, https://doi.org/10.1006/jaer.2000.0555.

31. Sozen, S.; Dulkadiroglu, H.; Yucel, A.B.; Insel, G.; Orhon, D. Pollutant footprint analysis for wastewater management in textile dye houses processing different fabrics. Journal of Chemical Technology and Biotechnology 2019, 94, 1330-1340, https://doi.org/10.1002/jctb.5891.

32. Sozen, S.; Karaca, C.; Alli, B.; Orhon, D. Sludge footprints of municipal treatment plant for the management of net useful energy generation beyond energy neutrality. Journal of Cleaner Production 2019, 215, 15031515, https://doi.org/10.1016/j.jclepro.2019.01.080.

33. APHA. Standard Methods for Examination of Water and Wastewater, 21 st ed.; American Public Health Association: USA, 2005.

34. Dogruel, S.; Altun, A.; Cokgor, E.U.; Insel, G.; Keskinler, B.; Orhon, D. Anatomy of the organic carbon in an industrial wastewater: Implications of particle size distribution, respirometry and process modelling. Process Safety and Environmental Protection 2021, 146, 257-266, https://doi.org/10.1016/j.psep.2020.09.002.

35. Dogruel, S.; Orhon, D. Particle size distribution as a major characteristic of domestic wastewater: implications for the modeling and design of membrane bioreactors. Journal of Chemical Technology and Biotechnology 2021, 96, 825-836, https://doi.org/10.1002/jctb.6645.

36. Gokcekus, H.; Orhon, D.; Duba, S.; Kakil, A.K.; Aslanova, F.; Sozen, S. Anatomy of the sequencing batch process for organic carbon removal from sewage with seasonal flow variations. Desalination and Water Treatment 2021, 215, 259-267, https://doi.org/10.5004/dwt.2021.26283. 
37. Artan, N.; Yagci, N.O.; Artan, S.R.; Orhon, D. Design of sequencing batch reactors for biological nitrogen removal from high strength wastewaters. Journal of Environmental Science and Health Part aToxic/Hazardous Substances \& Environmental Engineering 2003, 38, 2125-2134, https://doi.org/10.1081/ese-120023340.

38. Murat, S.; Insel, G.; Artan, N.; Orhon, D. Effect of temperature on the nitrogen removal performance of a sequencing batch reactor treating tannery wastewater. Water Science and Technology 2003, 48, 319-326, https://doi.org/10.2166/wst.2004.0870.

39. Tünay, O.; Kabdaşl1, I.; Gun, O. Sequencing batch reactor treatment of leather tanning industry wastewaters. Fresenius Environmental Bulletin 2004, 13, 945-950.

40. Dulekgurgen, E.; Yesiladali, K.; Ovez, S.; Tamerler, C.; Artan, N.; Orhon, D. Conventional morphological and functional evaluation of the microbial populations in a sequencing batch reactor performing EBPR. Journal of Environmental Science and Health Part a-Toxic/Hazardous Substances \& Environmental Engineering 2003, 38, 1499-1515, https://doi.org/10.1081/ese-120021474.

41. Germirli, F.; Orhon, D.; Artan, N. Assessment of the initial inert soluble cod in industrial wastewaters. Water Science and Technology 1991, 23, 1077-1086. 